\title{
Die Zukunftsarbeit der deutjacen Schule in der Türkei
}

\section{Dr. w. Blankenburg}

Đberlehrer, m. o. A

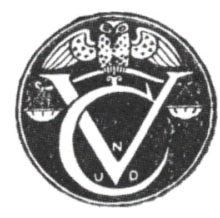

$\overline{\text { verlag von peit \& Comp., Eeipzig } 1915}$ 
Druch von Mefger $*$ Wittig in Selp3ig. 